\title{
THE ORIGIN OF KIMBERLITE AND LAMPROITE IN VEINED LITHOSPHERIC MANTLE
}

Foley, S.F.

\author{
Mineralogisch-Petrologisches Institut, Universität Göttingen, Goldschmidtstrasse 1, 3400 Göttingen, Gormany
}

Widely accepted models for the origin of alkaline magmas implicitly assume large-scale homogeneity and equilibrium in the mantle source regions by invoking partial melting of garnet lherzolite. A petrogenetic grid based on partial melting experiments on lherzolitic compositions works well for the voluminous basalt types from picrites to alkali basalts, but is less successful for more alkaline magma types. The presence of volatiles has been recognised as necessary for the genesis of $e . g$. basanites and nephelinites $\left(\mathrm{H}_{2} \mathrm{O}\right)$ and melilitites and kimberlites $\left(\mathrm{CO}_{2}\right)$, but the action of volatiles has been consistently envisaged as being superimposed on the same underlying assumption of homogeneous lherzolite. Thus, carbonated garnet lherzolite and phlogopite lherzolite are normally considered as sources for kimberlites and ultrapotassic rocks (e.g. Wyllie, 1980; Wendlandt and Eggler, 1980)

Increasingly, the need for "heterogeneity" and different "domains", "components" or "reservoirs" is discussed, but without a clear picture of the physical structure of the upper mantle source being developed. Strongly alkaline melts are gejerally accepted to originate by very small degrees of partial melting, and the influence of incompatible element-enriched accessory minerals is often invoked to explain patterns of minor and trace elements. In some cases, e.g. calcite, dolomite and alkali titanates, these accessory minerals are either believed or known not to be stable in lherzolite at upper mantle pressures.

A more realistic scheme than the homogeneous lherzolite model invokes a veined source rock composed of veins derived by solidification of earlier magma batches and wall-rocks of variably depleted lithospheric peridotite. Melt source regions for alkaline magmas are thus minute windows centred on these veins; homogeneity and equilibrium, if present at all, are only very local.

Composite nodules have provided many dyke-margin samples from about $100 \mathrm{~km}$ depth, and geobarometric estimates indicate that veined nodules from southern African kimberlites originate from as deep as $170 \mathrm{~km}$. Thus the brittle regime, characterised by flow through fractures as opposed to flow along grain boundaries, extends to at least $170 \mathrm{~km}$ beneath some cratons, and its persistence to depths in excess of $200 \mathrm{~km}$, applicable to the source regions of kimberlites and olivine lamproites, is not unreasonable. The transition zone between this brittle zone and the underlying grain boundary flow (GBF) regime has been modelled by sleep (1988) as a region in which veins collect melt from a restricted surrounding volume by grain boundary flow, and in which the proportion of veins increases upwards. A densely veined lower boundary to the brittle regime is thus a logical consequence of this scenario (McKenzie, 1989).

Melting processes in veined source rocks

The initial stages of melting will be centred on the vein assemblage due to the concentration of carbonate and hydrous minerals, many of which are enriched in incompatible elements. Evidence from (i) the few available near-solidus high-pressure experiments on basaltic compositions, and (ii) the parageneses of composite mantle xenoliths, suggests that the veins will consist dominantly of clinopyroxene and mica or amphibole, and will be essentially olivine-free. Minerals which are present only as accessories in lherzolite may be common (e.g. apatite).

Partial melting experiments by Lloyd et al. (1985) showed that lowalumina ultrapotassic melts can be produced by $30 \%$ melting of micapyroxenite. Titanates remained stable in the residuum to in excess of $30 \%$ melting, apatite to $>20 \%$ melting.

With continued melting of the vein-plus-wall-rock system, the veins and host peridotite do not behave as distinct systems, despite their 
inherently different solidus temperatures, because of the operation of solid-solution melting reactions which bridge the gap between the melting temperatures of the different assemblages. A well-known example of the solid solution melting effect is the Cr/Al ratio of spinel: peridotites depleted by loss of a basaltic melt fraction retain a Cr-rich spinel, whereas the Al-component is lost preferentially to the melt.

Solid solution melting reactions occur wherever a mineral contains end-members with greatly differing thermal stabilities. For vein assemblages in the subcontinental lithosphere, amphibole and mica, and probably to a lesser extent apatite and titanates, will exhibit important solid solution melting behaviour. Recent experiments on the hydroxy- and fluor-end-members of pargasite and K-richterite, which are the most likely amphiboles to be stable in lherzolite and harzburgite respectively, show that the fluor end-members are more stable by $150-250^{\circ} \mathrm{C}$ and $10-15$ Kbar relative to the $\mathrm{OH}-\mathrm{end}-$ members (Fig.1). Furthermore, the temperature difference for $\mathrm{K}-\mathrm{rich}$ terite increases with increasing pressure towards lower lithosphere levels relevant to kimberlite and olivine lamproite genesis. In experiments in the system kalsiliteforsterite-quartz with $\mathrm{H}_{2} \mathrm{O}$ or $F$, the peritectic point $\mathrm{Ol}_{+} \mathrm{Opx}+$ Phl+Lq, which models partial melting of a mica-bearing ultramafic assemblage, indicates that the corresponding difference between $\mathrm{F}$ and $\mathrm{OH}$ end-members for phlogopite is $320^{\circ} \mathrm{C}$ at $28 \mathrm{Kbar}$.

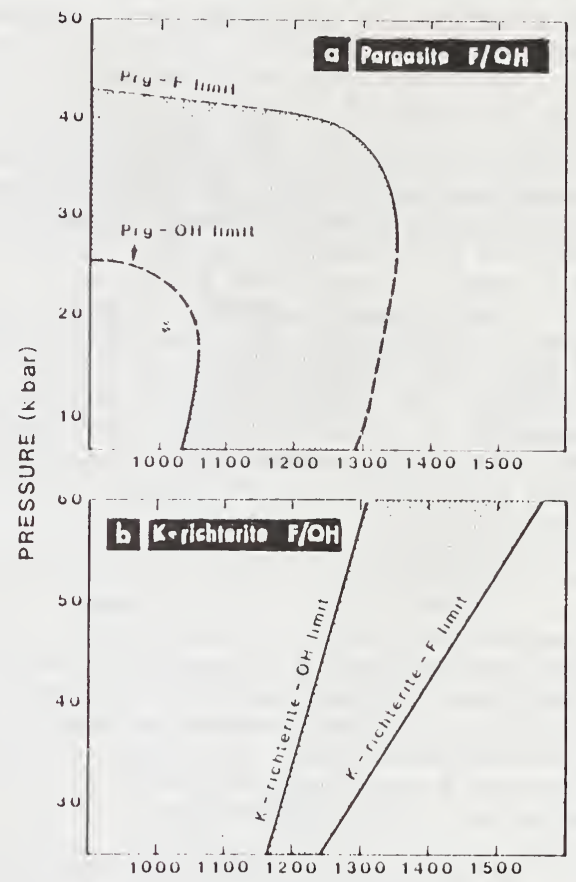

TEMHEHATURE ( $\left.{ }^{\circ} \mathrm{C}\right)$

The effect of the solid solution melting reactions is a smooth progression from vein melting to melting of the surrounding wall-rocks, so that an initial vein-derived strongly alkaline melt fraction becomes increasingly diluted by a more basaltic melt fraction from the wall-rocks.

Melting of veined lithosphere exhibits the following important general features:

(i) Magmas seen at the Earth's surface are hybrids of melt components derived from veins (V-component) and surrounding peridotitic wall-rock ( $\mathrm{W}$-component). The alkalinity of the magma broadly reflects the $\mathrm{V} / \mathrm{W}$ ratio.

(ii) The carbonate and/or hydrous minerals in the source are already concentrated into veins; they may be rare (or absent) in the surrounding wall-rock. This contrasts with most petrogenetic models in which these minerals are homogeneously distributed.

(iii) The chemistry of the $\mathrm{V}$-component may be controlled by minerals which are insignificant or even unstable in spinel- or garnet lherzolite. Examples are K-richterite and alkali-chrome-titanates which are almost certainly restricted to alkali-rich and alumina-poor environments.

(iv) The composition of the hybrid magma will be dependent on variations in (a) the nature of the melt which solidifies to form the veins, (b) the wall-rock assemblage, and (c) the conditions of melting, such as pressure, $\mathrm{fO}_{2}$ and volatile speciation.

(v) Solid-solution is of paramount importance, and cannot be neglected as in many peridotite melting models, especially those in simple systems. The stability of phlogopite and amphibole during a large melting 
interval makes these important buffer phases for many incompatible trace elements.

(vi) At larger degrees of melting than for strongly alkaline melts (i.e. lower $\mathrm{V} / \mathrm{W}$ ratios), commoner basaltic melt types will result. The incompatible element patterns of these basaltic rocks may nevertheless be attributable to vein components, and thus may show similar characteristics, but different abundances, to strongly alkaline rocks. In zones of extension, these vein components may be further diluted by an asthenospheric basalt component.

\section{Genesis of kimberlites}

A veined source explains the well-known hybrid characteristics of kimberlite, namely its alkaline and carbonate-rich, but nevertheless very magnesian nature. The conditions in the source noted in (iv) above can be constrained: The V-component must be carbonate-rich and thus oxidized, whereas the wall-rock is in most cases garnet lherzolite, as indicated by the occurrence of $\mathrm{Ol}, \mathrm{Opx}, \mathrm{Cpx}$ and $\mathrm{Gt}$ together near the liquidus of an average kimberlite composition (Eggler and Wendlandt, 1979).

The carbonate-rich vein material may be produced by partial melting of peridotite in the presence of $\mathrm{CO}_{2}$ and $\mathrm{H}_{2} \mathrm{O}$; this has been shown to produce $\mathrm{Na}$-carbonatitic melts at 20-30 Kbar (Wallace and Green, 1988), and may lead to Na-poorer, Ca-richer melts with very low silica contents at higher pressures due to the greater solution of $\mathrm{Na}_{2} \mathrm{O}$ in $\mathrm{Cpx}$ (Brey et al., 1991). This vein component would explain the correlation between CaO and $\mathrm{CO}_{2}$ in kimberlites as being due to a melt and not a $\mathrm{CO}_{2}$-rich fluid (cf. Bailey, 1984). Partial melting of lherzolite at 50-70 Kbar produces very Mg-rich melts, which together with abundant xenolithic material, impart the 'peridotitic' character to kimberlite. The Vw-model differs from that of McKenzie (1989) in that low-degree melts from the grain boudary flow regime are here seen as the source for only the first-stage vein assemblages, which eventually give rise to only the first of two components of the kimberlite magma; the GBF melts themselves are nowhere seen at the Earth's surface.

\section{Genesis of lamproites}

Mica is abundant in the vein assemblages of ultrapotassic rock sources, and remains stable in the residuum of at least the lamproites. The low $\mathrm{CaO}, \mathrm{Al}_{2} \mathrm{O}_{3}$ and $\mathrm{Na}_{2} \mathrm{O}$ of lamproites indicates a harzburgite or very depleted lherzolite wall-rock, since residual minerals of the source region as a whole are $\mathrm{Phl}, \mathrm{Ol}$ and Opx (Foley, 1989a).

The vein paragenesis cannot be closely defined at present because of the dearth of experimental work on non-lherzolitic ultramafic assemblages. The stability of $\mathrm{Cpx}$ is extremely sensitive to $\mathrm{fO}_{2}$ in lamproitic compositions, but is unlikely to be important in the source since $\mathrm{fO}_{2}$ is very low: low $\mathrm{fO}_{2}$ is indicated by the behaviour of mica chemistry, which can cause the extremely high $\mathrm{K} / \mathrm{Al}$ of lamproites only in reduced conditions (Foley 1989b). Incompatible element-rich accessory phases such as priderite, apatite and wadeite may be present in the vein assemblage.

Bailey, D.K. (1984) in Kimberlites I: kimberlites and related rocks (ed. J.Kornprobst) 323-333, Elsevier, Amsterdam.

Brey, G.P., Ryabchikov, I.D. and Bulatov, V. (1991) N.Jb.Min.Mh.

Eggler, D.H. and Wendlandt, R.F. (1979) in Kimberlites, diatremes and diamonds (eds. F.R.Boyd and H.O.A.Meyer) 330-338, Am. Geophys. Union, Washington.

Foley, S.F. (1989a) in Kimberlites and related rocks I (eds. A.L.Jaques, J.Ferguson and D.H.Green) 616-632, Blackwells, Melbourne.

Foley, S.F. (1989b) Eur. J. Mineral. 1, 411-426

McKenzie, D. (1989) Earth Planet.SCi.Lett. 95, 53-72

Sleep, N.H. (1988) J.Geophys.Res. 93, 10255-10272

Wallace, M.E. and Green, D.H. (1988) Nature 335, 343-346

Wendlandt R.F. and Eggler, D.H. (1980) Am.J.SCi. 280, 421-458

Wyllie, P.J. (1980) J.Geophys.Res. 85, 6902-6910 